\title{
Investigation of the thermodynamic and thermal properties of clary sage (Salvia sclarea L.) essential oil and its main components
}

\author{
Stanislava Tasheva $^{1 *}$, Vanya Gandova ${ }^{1}$, Vanya Prodanova-Stefanova ${ }^{2}$, Krasimira \\ Marinova $^{3}$, Milen Dimov ${ }^{2}$, Krasimira Dobreva ${ }^{2}$ and Albena Stoyanova ${ }^{1}$ \\ ${ }^{1}$ University of Food Technologies, 4002 Plovdiv, Bulgaria \\ ${ }^{2}$ Trakia University, Dept. Food Technology, 8600 Yambol, Bulgaria \\ ${ }^{3}$ University 'Prof. Assen Zlatarov', 8010 Bourgas, Bulgaria
}

\begin{abstract}
The some physochemical and chemical properties of the clary sage (Salvia sclarea L.) essential oil were determined. The main constituents in the clary sage essential oil (above $2 \%$ ) were: linalyl acetate (34.62\%), $\beta$-linalool (17.67\%), $\alpha$-muurolene $(8.27 \%), \beta$-caryophyllene (5.60\%), $\alpha$-ylangene (5.18\%), $\alpha$-terpineol $(4.84 \%), \mathrm{n}$-docosane $(3.00 \%)$, and neryl acetate $(2.34 \%)$. The thermodynamic and thermal properties of essential oil and its main components were investigated.
\end{abstract}

\section{Introduction}

Clary sage essential oil is obtained by steam distillation of flowering tops and foliage of cultivated Salvia sclarea L. (Lamiaceae). The main compounds in the oil were linalyl acetate (56-78\%) and linalool (6.5-24\%) [1-8]. In the plant were identified polyphenolic compounds, sesqui- and diterpenes [9-12].

The thermal properties of borage (Borago officinalis L.) seeds were determined at temperatures ranging from 6 to $20^{\circ} \mathrm{C}$ and moisture contents from 1.2 to $30.3 \%$ [13].

Some authors were reported of viscosities and densities, at $T=298.15 \mathrm{~K}$ of the phases formed after diterpenation of bergamot, lemon and mint essential oils, by (liquid + liquid) extraction [14].

In the literature do not found data for determination of thermodynamic parameters of clary sage essential oil as well as its main components which is also the aim of the present study.

\section{Material and methods}

2.1 Materials. Clary sage oil was provided by Kateco Ltd, Bulgaria. The oil was kept in the refrigerator at $4{ }^{\circ} \mathrm{C}$ before analysis.

\footnotetext{
* Corresponding author: st_tasheva@abv.bg
} 
2.1.1 Determination of refractive index. The refractive index $\left(\begin{array}{ll}n & 20 \\ D\end{array}\right)$ was determined according to ISO 280:1998 [15].

2.1.2 Determination of relative density. The refractive density $\left(\begin{array}{ll}d & 20 \\ 20\end{array}\right)$ was determined according to ISO 279:1998 [16].

2.1.3 Infrared spectroscopy of clary sage oil. The infrared spectrum was recorded using a Nicolet iS 50 Thermo Scientific FT-IR spectrometer in the frequency region of 4000-400 $\mathrm{cm}^{-1}$, with the samples embedded in $\mathrm{KBr}$ matrixes.

2.1.4 Chemical composition of the essential oil. GC analysis was performed using gas chromatograph Agilent 7890A [17]

2.1.5 Thermodynamic and thermal properties of the essential oil and its main compounds. Specific heat capacity is obtained by eq. (1) [18]:

$$
C_{p}=\left(\frac{\mathrm{dH}}{\mathrm{dT}}\right)_{P}
$$

where: $\mathrm{C}_{\mathrm{p}}$ - specific heat capacity, $\mathrm{J}_{\mathrm{mol}}{ }^{-1} \mathrm{~K}^{-1} ; \mathrm{H}$ - enthalpy, $\mathrm{J} \cdot \mathrm{mol}^{-1} ; \mathrm{T}$ - temperature, ${ }^{\circ} \mathrm{K}$. Dependence between specific heat capacity, thermal conductivity and coefficient of thermal conductivity were determined according to $[13,18]$ by eq. (2).

$$
a=\frac{\lambda}{\rho C_{p}}
$$

where: a - coefficient of thermal conductivity, $\mathrm{m}^{2} \cdot \mathrm{s}^{-1} ; \lambda$ - thermal conductivity, $\mathrm{W} \cdot \mathrm{m}^{-1} \mathrm{~K}^{-1}$; $\mathrm{C}_{\mathrm{p}}$ - specific heat capacity, J.mol ${ }^{-1} \mathrm{~K}^{-1} ; \rho$-density, $\mathrm{kg} \cdot \mathrm{m}^{-3}$.

2.1.6 Statistical analysis. The experimental data were obtained after three replicates. The results are presented as a mean value of the individual measurements with the corresponding standard deviation (SD).

\section{Results and Discussions}

The clary sage essential oil presented light yellow with a specific odor and had followed properties: density $0.8623 \pm 0.0$ and a refractive index $\left(n_{D}^{20}\right) 1.4635 \pm 0.0$. The obtained values didn`t exhibited differences with similar data from literature [1,2].

The IR spectrum of clary sage essential oil is presented in Table 1. The analysis of FTIR of studied oil represents mainly strong vibrations of the components in this oil. Intense line at $3423 \mathrm{~cm}^{-1}$ appears stronger connected with conformation in the $\beta$-linalool molecule. In this case the mixture $\mathrm{OH}$-groups lose steric factor.

Another connection with the spectrum of pure $\beta$-linalool is the band at $2973 \mathrm{~cm}^{-1}$ and associated with $\mathrm{CH}_{2}$-asymmetric vibrations. The probable cause of this behavior can be explained with antagonism with different bands from different components in the investigated oil. The other components does not show strong absorption bands because the limitations of FT-IR method which detects chemical compounds with concentration above $5 \%$.

The experimental FT-IR spectrum of clary sage essential oil is the presented in Fig. 1. 
Table 1. IR spectrum of clary sage essential oil

\begin{tabular}{|c|c|c|}
\hline \multicolumn{2}{|c|}{ Characteristic bands $\left(\mathrm{cm}^{-1}\right)$} & \multirow{2}{*}{ Group type } \\
\hline Experimental data & Reference data & \\
\hline 3423 & $\begin{array}{l}3550-3400 \\
3590-3420\end{array}$ & $\gamma \mathrm{OH}$ intramolecular $\mathrm{H}-$ bond \\
\hline 2973 & $2970-2950$ & linear $\gamma_{\mathrm{as}} \mathrm{CH}_{3}$ \\
\hline 2928 & $2940-2915$ & $\gamma_{\mathrm{as}}-\mathrm{CH}_{2}-$ \\
\hline 1735 & $1740-1720$ & $\begin{array}{l}\mathrm{R}-\mathrm{CHO} \gamma_{\mathrm{C}=0} \text {; characteristic band of carbonyl } \\
\text { group }\end{array}$ \\
\hline 1640 & $1648-1640$ & $\begin{array}{l}\text { non-conjugated } \mathrm{C}=\mathrm{C} \text {, low intensity. } \mathrm{HRC}=\mathrm{CH}_{2} \text { end } \\
\text { vinyl }\end{array}$ \\
\hline 1450 & $1465-1440$ & aromatic ring \\
\hline 1412 & $1435-1405$ & $-\mathrm{CH}_{2}-\mathrm{CO}-;$ vibrations of ketones, $\delta \mathrm{CH}_{2}$ \\
\hline 1375 & $1385-1370$ & a structural fragment of the type $\mathrm{C}\left(\mathrm{CH}_{3}\right)_{2}$ \\
\hline 1250 & $1260-1240$ & $\begin{array}{l}\text { a characteristic band for ether bond, of the type } \gamma^{\text {as }} \\
\text { C }-\mathrm{O}-\mathrm{C}\end{array}$ \\
\hline 1172 & $1175-1165$ & $\begin{array}{l}\text { a characteristic band for ether bond, of the type } \\
\mathrm{CH}_{3}-\mathrm{CH}-\mathrm{CH}_{3}\end{array}$ \\
\hline 1088 & $1150-1050$ & $\gamma^{\text {as }} \mathrm{C}-\mathrm{O}-\mathrm{C}$, ether bond \\
\hline 1047 & $1070-1020$ & $=\mathrm{C}-\mathrm{O}-\mathrm{C}, \gamma^{\mathrm{s}} \mathrm{C}-\mathrm{O}-\mathrm{C}$, aromatic and vinyl \\
\hline 921 & $925-905$ & $\mathrm{C}-\mathrm{H}$ bond of the type $\mathrm{HRC}=\mathrm{CH}_{2}$ \\
\hline 879 & $900-865$ & $\begin{array}{l}\text { trisubstituted aromatic ring } \gamma \mathrm{Ar}-\mathrm{H} \text { in positions } \\
1,2,4\end{array}$ \\
\hline
\end{tabular}

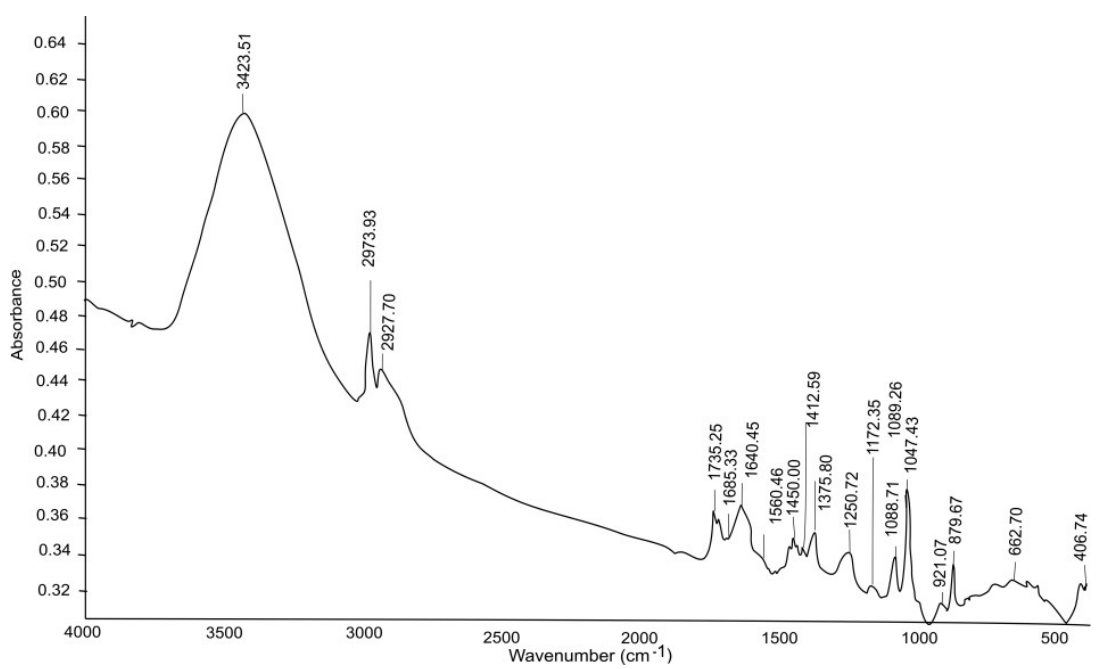

Fig. 1. IR spectrum of clary sage essential oil

Chemical composition of the clary sage essential oil is listed in Table 2.

From Table 2 as can see the oil contained 33 components representing $98.39 \%$ of the total content were identified. Fourteen of them were in concentrations over $1 \%$ and the rest 19 constituents were in concentrations under $1 \%$. The main components in the essential oil (above $2 \%$ ) from fruits were: linalyl acetate $(34.62 \%), \beta$-linalool $(17.67 \%), \alpha$-muurolene (8.27\%), $\beta$-caryophyllene (5.60\%), $\alpha$-ylangene (5.18\%), $\alpha$-terpineol (4.84\%), $\mathrm{n}$-docosane $(3.00 \%)$, and neryl acetate $(2.34 \%)$. 
Table 2. Chemical composition of clary sage essential oil

\begin{tabular}{|c|c|c|c|}
\hline № & Compounds & RI & Content, $\%$ \\
\hline 1. & $(2 \mathrm{E}, 4 \mathrm{E})$-Hexadienol & 912 & $0.15 \pm 0.0$ \\
\hline 2. & $\beta$-Myrcene & 988 & $1.82 \pm 0.01$ \\
\hline 3. & Limonene & 1025 & $1.05 \pm 0.01$ \\
\hline 4. & (Z)- $\beta$-Ocimene & 1039 & $0.22 \pm 0.0$ \\
\hline 5. & (E)- $\beta$-Ocimene & 1049 & $1.59 \pm 0.01$ \\
\hline 6. & $\alpha$-Terpinolene & 1084 & $0.56 \pm 0.0$ \\
\hline 7. & $\beta$-Linalool & 1090 & $17.67 \pm 0.17$ \\
\hline 8. & $\alpha$-Terpineol & 1188 & $4.84 \pm 0.04$ \\
\hline 9. & Linalyl formate & 1215 & $0.18 \pm 0.0$ \\
\hline 10. & Nerol & 1230 & $0.15 \pm 0.0$ \\
\hline 11. & Geraniol & 1249 & $0.83 \pm 0.0$ \\
\hline 12. & Linalyl acetate & 1254 & $34.62 \pm 0.33$ \\
\hline 13. & Geranyl formate & 1297 & $0.10 \pm 0.0$ \\
\hline 14. & Citronellyl acetate & 1350 & $0.15 \pm 0.0$ \\
\hline 15. & Neryl acetate & 1361 & $2.34 \pm 0.02$ \\
\hline 16. & $\beta$-Ylangene & 1373 & $5.18 \pm 0.05$ \\
\hline 17. & $\beta$-Cubebene & 1386 & $0.33 \pm 0.0$ \\
\hline 18. & $\beta$-Bourbonene & 1389 & $0.38 \pm 0.0$ \\
\hline 19. & $\beta$-Caryophyllene & 1420 & $5.60 \pm 0.05$ \\
\hline 20. & Aromadendrene & 1439 & $0.27 \pm 0.0$ \\
\hline 21. & $\alpha$-Caryophyllene & 1455 & $0.30 \pm 0.0$ \\
\hline 22. & $\gamma$-Muurolene & 1478 & $0.60 \pm 0.0$ \\
\hline 23. & $\alpha$-Muurolene & 1496 & $8.27 \pm 0.08$ \\
\hline 24. & Viridiflorene & 1499 & $0.74 \pm 0.0$ \\
\hline 25. & $\gamma$-Cadinene & 1513 & $1.61 \pm 0.01$ \\
\hline 26. & $\delta$-Cadinene & 1522 & $0.97 \pm 0.0$ \\
\hline 27. & $\beta$-Cadinene & 1537 & $1.56 \pm 0.01$ \\
\hline 28. & Spathulenol & 1577 & $0.72 \pm 0.0$ \\
\hline 29. & (2-Z,6-E)-Farnesyl acetate & 1821 & $1.12 \pm 0.01$ \\
\hline 30. & $n$-Nonadecane & 1900 & $0.53 \pm 0.0$ \\
\hline 31. & $n$-Eicosane & 2000 & $0.37 \pm 0.0$ \\
\hline 32. & $n$-Heneicosane & 2100 & $0.57 \pm 0.0$ \\
\hline 33. & $n$-Docosane & 2200 & $3.00 \pm 0.03$ \\
\hline
\end{tabular}

The difference in the quantities of chemical composition of our essential oil and the reported data [1-8] may be due to environmental conditions under which the plant has grown as well as the variation in conditions of analysis. 
Distribution of major groups of aroma substances in the essential oil is shown in Figure 2. The dominant groups in the oil were oxygenated monoterpenes $(61.88 \%)$; then followed by sesquiterpene hydrocarbons $(26.23 \%)$, monoterpene hydrocarbons $(5.33 \%)$, and hydrocarbons $(4.54 \%)$, oxygenated sesquiterpenes $(1.87 \%)$, and oxygenated hydrocarbons $(0.15 \%)$.

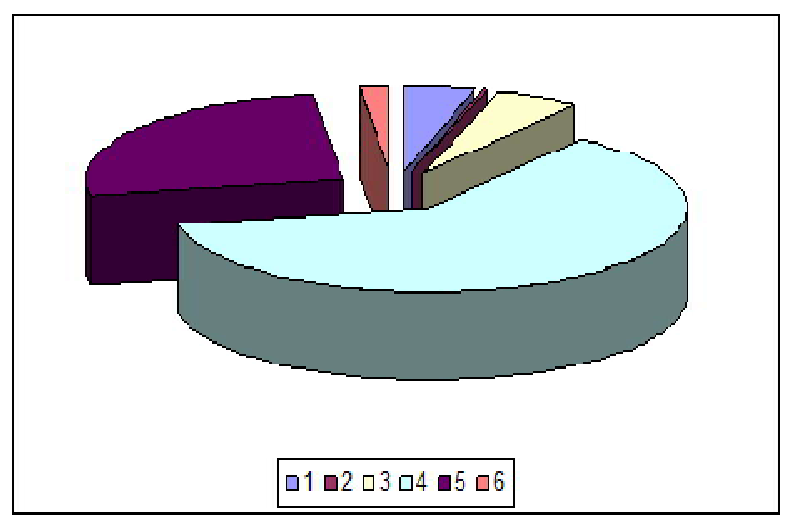

Fig.2. Group of components in clary sage essential oils, \%.

1 - hydrocarbons; 2 - oxygenated hydrocarbons; 3 - monoterpene hydrocarbons; 4 - oxygen monoterpenes; 5 - sesquiterpene hydrocarbons; 6 - oxygenated sesquiterpenes.

In Table 3 are presented some chemical properties of the main nine aromatic substances, which formed $82.85 \%$ from total composition. It was determined scent and properties of the essential oil, too. The investigated substances were $\beta$-linalool, $\alpha$-terpineol, linalyl acetate, and neryl acetate which are the main components from oxygen monoterpenes group, $\alpha$-muurolene, $\beta$-caryophyllene, and $\beta$-ylangene - from sesquiterpene hydrocarbons group and $\mathrm{n}$-docosane from hydrocarbons group. There distribution by functional groups and structure is: hydrocarbons ( $\alpha$-muurolene, $\beta$-caryophyllene, $\beta$ ylangene, and n-docosane), two alcohols (linalool and $\alpha$-terpineol), and two esters (linalyl acetate and neryl acetate).

The calculations of thermo physical characteristics of the clary sage essential oil as well as thermal conductivity, specific heat capacity and coefficient of thermal conductivity are presented in Table 4. The values are obtained according to the chemical composition presented in Table 2.

The results compared with literature data of the same parameters, which is obtained experimentally [13] where: $\lambda=0.11-0.28 \mathrm{~W} \cdot \mathrm{m}^{-1} \mathrm{~K}^{-1} ; \mathrm{Cp}=0.77-1.99 \kappa \mathrm{J} \cdot \mathrm{mol}^{-1} \mathrm{~K}^{-1}$; $\mathrm{a}=$ $2.32 \cdot 10^{-7}-3 \cdot 18 \cdot 10^{-7} \mathrm{~m}^{2} \cdot \mathrm{s}^{-1}$. 
Table 3. Thermo physical parameters of the main compounds [19]

\begin{tabular}{|c|c|c|c|c|c|c|c|c|}
\hline Compounds & Ylangene & $\begin{array}{c}\beta- \\
\text { Caryophyllene }\end{array}$ & $\begin{array}{c}\alpha- \\
\text { Muurolene }\end{array}$ & $\begin{array}{c}n- \\
\text { Docosane }\end{array}$ & $\beta$-Linalool & $\begin{array}{c}\alpha- \\
\text { Terpineol }\end{array}$ & $\begin{array}{c}\text { Neryl } \\
\text { acetate }\end{array}$ & Linalyl acetate \\
\hline Empirical Formula & $\mathrm{C}_{15} \mathrm{H}_{24}$ & $\mathrm{C}_{15} \mathrm{H}_{24}$ & $\mathrm{C}_{15} \mathrm{H}_{24}$ & $\mathrm{C}_{22} \mathrm{H}_{46}$ & $\mathrm{C}_{10} \mathrm{H}_{18} \mathrm{O}$ & $\mathrm{C}_{10} \mathrm{H}_{18} \mathrm{O}$ & $\mathrm{C}_{12} \mathrm{H}_{20} \mathrm{O}_{2}$ & $\mathrm{C}_{12} \mathrm{H}_{20} \mathrm{O}_{2}$ \\
\hline Molecular Weight & 204.35 & 204.32 & 204.35 & 310.60 & 154.25 & 154.25 & 196.29 & 196.29 \\
\hline$\Delta \mathrm{fH}^{\mathrm{o}}$ gas, $\mathrm{kJ} . \mathrm{mol}^{-1}$ & -125.10 & -112.68 & -164.97 & -497.41 & -177.85 & -310.08 & -320.95 & -311.70 \\
\hline$\Delta$ fusH ${ }^{\circ}, \mathrm{kJ} \mathrm{mol}^{-1}$ & 20.07 & 14.82 & 21.69 & 52.74 & 15.94 & 11.00 & 27.41 & 19.82 \\
\hline$\Delta \mathrm{vapH}^{\mathrm{o}}, \mathrm{kJ} \cdot \mathrm{mol}^{-1}$ & 47.69 & 65.50 & 50.71 & $\begin{array}{c}{[111.90 ;} \\
115.60]\end{array}$ & 65.00 & 54.62 & 51.54 & 49.53 \\
\hline $\log$ Potc/wat & 4.27 & 4.73 & 4.58 & 8.83 & 2.67 & 2.50 & 3.24 & 3.24 \\
\hline $\mathrm{Pc}, \mathrm{kPa}$ & 2001.91 & 2027.23 & 1921.98 & 10000.00 & 2581.96 & 2950.48 & 2047.46 & 2054.89 \\
\hline Tboil, K & 561.69 & 576.30 & 576.33 & 641.80 & $\begin{array}{l}{[468.70 ;} \\
471.80]\end{array}$ & 490.70 & 407.20 & 493.20 \\
\hline Tc, K & 775.53 & 802.06 & 791.72 & 786.00 & 697.57 & 740.92 & 748.06 & 740.67 \\
\hline Tfus, K & 322.81 & 323.71 & 287.93 & $\begin{array}{l}{[313.20 ;} \\
318.30]\end{array}$ & 244.90 & 308.15 & 259.08 & 278.78 \\
\hline $\mathrm{Vc}, \mathrm{m}^{3} \cdot \mathrm{kg}^{-1} \mathrm{~mol}^{-1}$ & 0.71 & 0.72 & 0.72 & 1.27 & 0.57 & 0.52 & 0.69 & 0.68 \\
\hline $\mathrm{Cp}$, liquid, J.mol ${ }^{-1} \mathrm{~K}^{-1}$ & $-*$ & - & - & 739.00 & 372.40 & - & - & - \\
\hline $\mathrm{Cp}$, solid, J.mol ${ }^{-1} \mathrm{~K}^{-1}$ & - & - & - & 563.60 & - & - & - & - \\
\hline
\end{tabular}

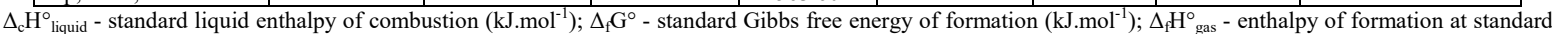
conditions $\left(\mathrm{kJ}_{\mathrm{mol}} \mathrm{mol}^{-1}\right) ; \Delta_{\mathrm{fus}} \mathrm{H}^{\circ}$ - enthalpy of fusion at standard conditions $\left(\mathrm{kJ}_{\mathrm{mol}} \mathrm{m}^{-1}\right) ; \Delta_{\mathrm{vap}} \mathrm{H}^{\circ}$ - enthalpy of vaporization at standard conditions $\left(\mathrm{kJ} . \mathrm{mol} \mathrm{l}^{-1}\right) ; \mathrm{P}_{\mathrm{c}}-\mathrm{critical}$ pressure $(\mathrm{kPa})$; $\mathrm{T}_{\text {boil }}$ - normal boiling point Temperature $(\mathrm{K}) ; \mathrm{T}_{\mathrm{c}}$ - critical temperature $(\mathrm{K})$; $\mathrm{C}_{\mathrm{p}, \text { gas }}$ - ideal gas heat capacity $\left(\mathrm{J}\right.$.mol $\left.{ }^{-1} \mathrm{~K}^{-1}\right)$; $\mathrm{C}_{\mathrm{p}, \text { liquid }}$ - liquid phase heat capacity $\left(\mathrm{J} \cdot \mathrm{mol}^{-1} \mathrm{~K}^{-1}\right)$; * no data. 
Table 4. Thermal parameters of the clary sage essential oil

\begin{tabular}{|c|c|c|c|c|c|}
\hline $\begin{array}{c}\text { Thermal } \\
\text { parameters }\end{array}$ & $\mathrm{R}_{\mathrm{cm}}, \mathrm{J} \cdot \mathrm{mol}^{-1} \mathrm{~K}^{-1}$ & $\mathrm{E}_{\mathrm{a}}, \mathrm{kJ} \cdot \mathrm{mol}^{-1}$ & $\mathrm{C}_{\mathrm{p}}, \mathrm{J} \cdot \mathrm{mol}^{-1} \mathrm{~K}^{-1}$ & $\begin{array}{c}\lambda .10^{3} \\
\text { W. } \mathrm{m}^{-1} \mathrm{~K}^{-1}\end{array}$ & $\begin{array}{l}\text { a. } 10^{6}, \\
m^{2} . s^{-1}\end{array}$ \\
\hline Clary sage oil & 43.58 & -1796.75 & 6026.32 & 330.31 & 1.49 \\
\hline $\begin{array}{c}\text { Thermal } \\
\text { Parameters }\end{array}$ & $\mathrm{M}_{\mathrm{cm}}, \mathrm{kg} \cdot \mathrm{mol}^{-1}$ & $\Delta \mathrm{H}, \mathrm{kJ} \cdot \mathrm{mol}^{-1}$ & $\Delta \mathrm{S}, \mathrm{kJ} \cdot \mathrm{mol}^{-1} \mathrm{~K}^{-1}$ & \multicolumn{2}{|c|}{$\Delta \mathrm{G}, \mathrm{kJ} \cdot \mathrm{mol}^{-1}$} \\
\hline Clary sage oil & 190.77 & 1796.75 & -14.34 & \multicolumn{2}{|c|}{6072.31} \\
\hline
\end{tabular}

$\mathrm{R}_{\mathrm{cm}}$ - universal gas constant, J.mol ${ }^{-1} \mathrm{~K}^{-1} ; \mathrm{E}_{\mathrm{a}}$ - activation energy, kJ.mol ${ }^{-1} ; \mathrm{C}_{\mathrm{p}}$ - specific heat capacity, J.mol ${ }^{-1} \mathrm{~K}^{-1} ; \lambda$ - thermal conductivity, W. ${ }^{-1} \mathrm{~K}^{-1} ; \mathrm{a}$ - coefficient of thermal conductivity, $\mathrm{m}^{2} \cdot \mathrm{s}^{-1} ; \mathrm{M}_{\mathrm{cm}}$, molar mass of the main components, $\mathrm{kg} \cdot \mathrm{mol}^{-1} ; \Delta \mathrm{H}$ - enthalpy, $\mathrm{kJ} \cdot \mathrm{mol}^{-1} ; \Delta \mathrm{S}$ - entropy, $\mathrm{kJ} \cdot \mathrm{mol}^{-1} \mathrm{~K}^{-1} ; \Delta \mathrm{G}$ - energy of Gibb`s, kJ.mol ${ }^{-1}$.

The activation energy was calculated about $-1796.75 \mathrm{~kJ} \cdot \mathrm{mol}^{-1}$. The negative value specified that processes were non-spontaneous occurring as a result of heat and light. The molar mass of clary sage oil was determined experimentally using GC/MS analysis (190.77 $\mathrm{kg} \cdot \mathrm{mol}^{-1}$ ). The thermodynamic parameters of Gibbs energy, enthalpy and entropy of the main components of sage essential oil were calculated. The thermodynamic parameters for salvia oil-ethanol-water solution were found in the literature [20], as the values obtained for

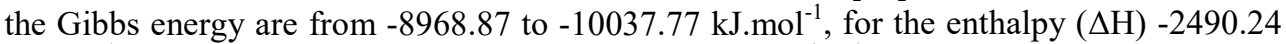
$\mathrm{kJ} . \mathrm{mol}^{-1}$ and for entropy $(\Delta \mathrm{S})$ from 21.71 to $24.83 \mathrm{~kJ} \cdot \mathrm{mol}^{-1} \mathrm{~K}^{-1}$. The differences in the values obtained are probably due to the different composition of the studied essential oils. In pure oils the values of the thermodynamic parameters depend mainly on the chemical composition of the obtained essential oil, and when used in solution the values are also influenced by the solvents. Gibbs energy represents a thermodynamic potential and shows the possibility of the process. The positive values of Gibbs energy mean that the process that takes place in the main components of the essential oil is spontaneous and irreversible. Entropy as a thermodynamic parameter gives a connection about the mechanism of the reaction and the activation complexes. In this case the entropy values are negative, which means that the process is irreversible. The enthalpy values are positive too, which also means that the process is irreversible. In this case the enthalpy of the process is equal to the activating energy with the opposite sign. This means that the process will proceed with the adding of energy.

Table 5 presented values of heat capacity and enthalpy of main components of clary sage oil. Composition of the all components are summarised to $100 \%$ needs for calculations of the molar heat capacity and enthalpy for each one of main components. Comparison between results given in Table 3 and Table 5 are done for $\mathrm{n}$-docosane and $\beta$-linalool. Differences which appeared between literature data $[14,19]$ (Table 3) and experimental values from this work probably connected for different composition of components in the essential oil. It didn`t found data for molar enthalpy of clary sage essential oil at $25^{\circ} \mathrm{C}$ in literature and for this reason no comparison was made of the results obtained in this work.

Table 5. Specific heat capacity and enthalpy of main components of clary sage essential oil

\begin{tabular}{|l|c|c|c|c|c|c|c|c|}
\hline Compounds & $\begin{array}{c}\text { Ylan } \\
\text { gene }\end{array}$ & $\begin{array}{c}\beta \text {-Caryo } \\
\text { phyllene }\end{array}$ & $\begin{array}{c}\alpha \text { - } \\
\text { Muuro } \\
\text { lene }\end{array}$ & $\begin{array}{c}n \text {-Doco } \\
\text { sane }\end{array}$ & $\begin{array}{c}\beta \text { - } \\
\text { Linalool }\end{array}$ & $\begin{array}{c}\alpha \text { - } \\
\text { Terpi- } \\
\text { eol }\end{array}$ & $\begin{array}{c}\text { Neryl } \\
\text { acetate }\end{array}$ & $\begin{array}{c}\text { Linalyl } \\
\text { acetate }\end{array}$ \\
\hline Content, $\%$ & 5.18 & 5.60 & 8.27 & 3.00 & 17.67 & 4.84 & 2.34 & 34.62 \\
\hline $\begin{array}{l}\mathrm{C}_{\mathrm{p}}, \mathrm{J} . \mathrm{mol}^{-} \\
{ }^{-} \mathrm{K}^{-1}\end{array}$ & 229.87 & 248.50 & 366.99 & 87.59 & 1038.79 & 284.54 & 108.10 & 1599.38 \\
\hline $\mathrm{h}_{\mathrm{i}, \mathrm{kJ} . \mathrm{mol}^{-1}}$ & 68.54 & 74.09 & 109.42 & 26.11 & 309.71 & 84.83 & 32.23 & 476.86 \\
\hline
\end{tabular}

$\mathrm{C}_{\mathrm{p}}$ - specific heat capacity, J.mol ${ }^{-1} \mathrm{~K}^{-1} ; \mathrm{h}_{\mathrm{i}}$ - enthalpy, $\mathrm{kJ} \cdot \mathrm{mol}^{-1}$. 


\section{Conclusions}

Some thermodynamic and thermo physical properties of the industrial clary sage essential oil and its major compounds were investigated. The chemical characteristic was done with two experimental methods FT-IR and GC/MS. The FT-IR analysis of studied oil represented mainly strong vibrations of major components in the studied oil.

1. Thermal conductivity $\lambda$ and coefficient of thermal conductivity were calculated as $330.31 .10^{-3} \mathrm{~W} \cdot \mathrm{m}^{-1} \mathrm{~K}^{-1}$ and $1.49 .10^{-6} \mathrm{~m}^{2} . \mathrm{s}^{-1}$ respectively.

2. The thermodynamic parameters of sage essential oil were calculated on the basis of its

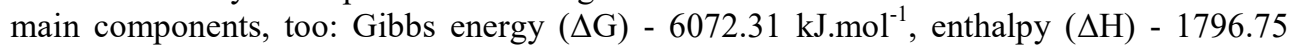
$\mathrm{kJ} \cdot \mathrm{mol}^{-1}$, and entropy $(\Delta \mathrm{S})-14.34 \mathrm{~kJ} \cdot \mathrm{mol}^{-1} \mathrm{~K}^{-1}$.

3. The specific heat capacity of sage oil and its main components are calculated, as well as the molar enthalpy of the main components.

\section{References}

1. K. Bauer, D. Garbe, H. Surburg, Common fragrance and flavor materials, Preparation, properties and uses, (fourth completely revised Edition, Weinheim, NewYork, Chichester, Brisbane, Singapore, Toronto, Wiley-VCH, 2001)

2. E. Georgiev, A. Stoyanova, A guide for the specialistin the aromatic industry. (UFT Acad. Publ. House, Plovdiv, Bulgaria, 2006)

3. E. Dimitrova, S. Ilieva, G. Zolotovitch, Compt Rend l'Acad Bul Sci, 8, 3, 13-16, (1955)

4. S. Ilieva, Herba Hungarica, 18, 3,197-203,(1979)

5. N. Kovatcheva, V. Zheljazkov, $7^{\text {th }}$ International Symposium on Essential Oils, Vienna, (1996)

6. Y. Hristova, V. Gochev, J. Wanner, L. Jirovetz, E. Schmidt, T. Grigorova, A. Kuzmanov, J BioSci Biotechn, 2, 1, 39-44 (2013)

7. T. Farukh, S. Sharopov, W. Setzer, Short Report, Rec. Nat. Prod., 6, 1, 75-79, (2012)

8. A. Peana, M. Moretti, C. Juliano, Planta Med., 65, 8, 752-754, (1999)

9. A. Caniard, P. Zerbe, S. Legrand, A. Cohade, N. Valot, J.-L. Magnard, J. Bohlmann, L. Legendre, BMC Plant Biology, 12, 119, (2012)

10. B. Maurer, A. Hauser, Presented, in part, at the $I^{\text {th }}$ International Congress of Essential Oils, Singapore, 66, 7, 2223-2235, (1983)

11. Ł. Kuźma', M. Różalski, E. Walencka, B. Różalska, H. Wysokińska, Phitomedicine, 14, 1, 31-35, (2007)

12. I. Jasicka-Misiak, A. Poliwoda, M. Petecka, O. Buslovych, V. Shlyapnikov, P. Wieczorek, Ecol. Chem. Eng. S., 25, 1, 133-142, (2018)

13. W. Yang, S. Sokhansanj, J. Tang, P. Winter, Biosystems Engineering, 82, 2, 169, (2002)

14. P. Florido, I. Andrade, M. Capellini, F. Carvalho, K. Aracava, C. Koshima, C. Rodrigues, C. Goncalves, J Chem Thermo-dynamics, 72, 152, (2014)

15. ISO 280:1998. Essential oils - Determination of refractive index. 
16. ISO 279:1998. Essential oils - Determination of relative density at $20{ }^{\circ} \mathrm{C}$ Reference method

17. S. Tasheva, V. Gandova, K. Dobreva, I. Dincheva, V. Prodanova-Stefanova, A. Stoyanova, RJPBCS, 10, 220-227, (2019).

18. F. Incropera, D. Dewitt, T. Bergam, A. Lavine, Fundaments of Heat and Mass Transfer,(John Wiley \&Sons, 2006)

19. https://www.chemeo.com

20. S. Tasheva, V. Gandova, K. Dobreva, V. Prodanova-Stefanova, K. Marinova, I. Dincheva, A. Stoyanova, E3W Conf. $25^{\text {th }}$ Sceintific Conference on Power Engineering and Power Mashines (PEPM'2020), 207, 01021, (2020) 